Revista Iberoamericana. Vol. LXVI, Núm. 190, Enero-Marzo 2000, 49-62

\title{
LA LECTURA COMO ACTO DE COMPLICIDAD AMOROSA (ENTREVISTA CON CRISTINA PERI ROSSI)
}

\author{
POR \\ MERCEDEs ROWINSKY \\ Wilfrid Laurier University
}

Esta entrevista con Cristina Peri Rossi se llevó a cabo en Barcelona los días 1 y 2 de julio de 1998. En ella, Peri Rossi nos abre su mundo para que podamos recorrer pasadizos que para muchos resultarán desconocidos. Es una oportunidad de "descubrir" algunos de los velos que el escritor mantiene cerrados en su mundo creativo. A lo largo de la misma, tenemos la oportunidad de tener una visión de esta creadora analizando diversas facetas del proceso de la escritura, no sólo de su obra de ficción, sino también de lo que ella llama su trabajo "intelectual” que concierne a su creación ensayística. Peri Rossi nos da también su opinión sobre el papel de la literatura en este nuevo siglo que se avecina esbozando así una perspectiva prometedora de la función de la literatura en nuestro futuro.

Mercedes Rowinsky: Quisiera comenzar esta entrevista con algo que te he querido preguntar por mucho tiempo: ¿qué piensas tú de nuestro trabajo de supuestos “críticos”término que en realidad a mí personalmente no me gusta mucho ya que nos da cierto poder, cuando en realidad es un privilegio que nos tomamos-cuando nos acercamos a textos literarios y tratamos de imponer significados que no son siempre los correctos?

Cristina Peri Rossi: Como escritora, uno sueña con el lector ideal que es el doble de uno mismo. El lector ideal ha leído los mismos libros que uno, ha visto las mismas películas, le gustan las mismas cosas, entiende los mismos guiños. Claro, ese lector no existe más que en nuestra imaginación. Es para quien uno escribe. Por lo menos ciertos escritores somos así, lo cual tiene la virtud de que te impide repetirte mucho, si no el lector puede terminar diciendo: "Esto ya lo leí” ¿no? Pienso que el sueño de uno, esa complicidad que tiene con el lector imaginario, la encuentra en un lector de carne y hueso, por lo tanto uno siempre está a la búsqueda de ese lector que entendió todo lo que uno creyó escribir.

$M R:$ ¿Tú piensas que es fácil encontrarlo?

$C P R$ : No, evidentemente es muy difícil encontrarlo. En cuanto yo publico el libro, la lectura que hace el otro es su lectura. Hay cosas muy curiosas, por ejemplo, hace un tiempo vino un periodista - a quien además le gustaba mucho mi poesía — y la entrevista iba muy bien y estábamos hablando del libro Aquella noche (1996). En el mismo hay un poema que se llama "Dolores”, que habla de los dolores físicos, que en realidad son otros dolores, o en todo caso de la relación psicosomática entre los dolores físicos y los dolores del alma. Pero nunca se me hubiera ocurrido la pregunta que él me hizo. Él me dijo: — “Dolores, ¿es el 
nombre de una mujer, no?” Claro, cuando yo escribí ese poema me olvidé por completo de que, además, Dolores es un nombre muy común en España, y, evidentemente, para él, algo había en su vida que le hizo recordar. Cuando vio "Dolores”, se acordó de una mujer.

$M R$ : De aquí que surjan tantas interpretaciones como lecturas se hagan muchas veces; ¿no?

$C P R$ : Eso tiene que ver estrictamente con que cada palabra, aunque hablemos la misma lengua, para cada uno de nosotros tiene campos referenciales distintos. Entonces, uno busca siempre al lector que tenga los referentes más aproximados a los que uno creyó que utilizaba; lo que uno buscó escribiendo. Yo pienso que la gente que estudia literatura está mejor preparada que la que no estudia, porque evidentemente hay cierto tipo de escritores, como yo, que escriben desde la literatura. Yo soy un animal literario. He estudiado mucha literatura. He leído infinidad de libros, por lo tanto, no soy el tipo de escritor espontáneo, de talento, digamos naive, que si un día le sale bien un poema, fenómeno, pero no tiene la menor idea de por qué le salió bien. Yo creo que soy absolutamente consciente de cada palabra, lo cual no le quita espontaneidad, porque yo creo que no escribo con el inconsciente, pero al escribir soy completamente consciente de mi inconsciente. Entonces, a mí lo mejor que me puede pasar es la sonrisa cómplice de la lectora en el momento en que yo creo que se tiene que sonreír. Yo no puedo recordar ni un poema mío, ni un cuento, ni una frase. Ahora, si tú vas leyendo un cuento mío en voz alta, o un poema, y te equivocas en una palabra, yo te digo la que va. ¿Cómo se puede explicar esto si yo no sé el poema?, si yo nunca lo he recordado ni lo he vuelto a leer? Eso quiere decir que el poema yo lo escribí con el inconsciente, y el inconsciente te corrige. Yo te digo sin ningún problema en qué palabra te equivocaste, y te digo la palabra exacta que va.

$M R: ~ ¿$ ¿Por qué crees que eso ocurre?

$C P R$ : Eso para mí es porque cuando escribo estoy en un momento de total concentración en cuanto a los posibles referentes a los que me refiero, que hacen absolutamente necesaria esa palabra y no otra. Es una cosa muy común que te puede pasar con los nombres de los personajes. Yo, por ejemplo, tuve un problema con Solitario de amor (1988). Yo sabía que quería que la mujer tuviera un nombre con "A". No sabía cuál. Cuando empecé a escribir la novela, eso no lo tenía resuelto, y la voz que me dictaba, me dictaba “A”. Yo escribí todo el original A. Una vez que escribí A. tuve que esperar mucho tiempo, porque además los escritores, nos encariñamos mucho con lo que hacemos, y durante ese tiempo no podemos ser críticos. Estamos tan involucrados que no podemos tocar aquello. No queremos cortarle nada ni quitarle nada. Entonces dejé pasar un tiempo, el suficiente como para que mi inconsciente ya aceptara que yo estaba dispuesta a publicar el libro con A., hasta que una parte, mi parte racional, me dijo: - "No, mira, A. no. Esto va a complicar innecesariamente el libro. Busca un nombre con A". Y estuve mucho tiempo hasta que encontré el nombre Aída, y vi que funcionaba. Otras veces, cuando utilizo el nombre de entrada de un personaje, me ha pasado que empiezo a escribir algo y le pongo un nombre, y de pronto me detengo y no sale nada más. Aquello no avanza para ningún lado, y me pongo muy inquieta. Entonces pienso, ¿qué pasa? Es que el nombre no le va al personaje. ¿Qué quiere decir que el nombre no le va? Que yo siento que en el mundo cultural, en el medio lingüístico en el que me estoy moviendo, los referentes que el lector le puede atribuir a ese nombre no tienen que ver con la psicología del personaje. Entonces yo tengo que encontrar un nombre adecuado, por eso 
es fundamental. Es tan importante como el nombre del cuento, o como el nombre de la novela, porque digamos que el texto manifiesto siempre, es nada más que uno de los textos, el otro está implícito. El texto implícito es fundamental. Yo pienso que uno escribe todo para no escribir lo que tendría que escribir. Justamente porque un viejo recurso psicológico del género humano es que aprendemos mejor con parábolas o con fábulas que tienen moraleja, que con ideas. Por ejemplo, la idea "tienes que ser bueno" no nos emociona, pero si escuchamos el relato de La Cenicienta, nos emocionamos. Nosotros aprendemos a través de la lectura.

MR: Eso es lo maravilloso de la lectura, el tratar de descubrir qué hay más allá de las palabras. Esa en realidad es la tarea de nosotros como estudiosos de la literatura, ¿no crees?

$C P R$ : Claro, entonces yo, lo que más espero, y creo que esperar es muchísimo, es que la persona que está leyendo se ría donde yo creo que se tiene que reír, como te lo expliqué antes.

MR: Eso me ocurre a mí como lectora. Cuando leo tu trabajo y me sonrío, te imagino a ti escribiendo y sonriendo.

$C P R$ : Claro, y yo imagino a ese lector sonriendo en ese momento. Por lo tanto, lo importante es la complicidad que se crea. La escritura es un acto de amor porque es un acto de complicidad. Es un acto de seducción, y por eso es también erótica. Yo tengo que intentar seducirte.

$M R$ : Para que uno no cierre el libro.

$C P R$ : Exacto, y para que aceptes lo inverosímil. Vamos a pensar en el comienzo maravilloso de La metamorfosis de Kafka. El personaje, Gregor Samsa, una mañana amaneció convertido en un gusano. El lector que sigue la lectura tiene que ser sumiso y aceptar la voluntad de Kafka de hacerle creer aquello que es inverosímil. Entonces tiene que decir: "Si me está contando esto que es inverosímil, será por algo". Por eso es que es tan importante la primera frase.

$M R$ : O lo dejas, o sigues.

$C P R$ : Claro. Yo, por ejemplo, no he podido leer Bajo del volcán, porque las primeras diez páginas jamás me han seducido.

MR: ¿Y lo has intentado varias veces?

$C P R$ : Sí, porque era el libro favorito de una amiga. Ella y yo no teníamos los mismos gustos, si no hubiéramos sido una réplica la una de la otra, y a veces discutíamos sobre esto. Ella decía que una de sus lagunas era que no sea capaz de gozar con Bajo del volcán. Entonces me decía: — “Sáltate las cincuenta primeras...”- — No”, le contestaba yo. "Si me tengo que saltar las cincuenta primeras, no lo leo". Hay diez mil libros que ya me enganchan desde la primera frase, entonces éste no es un libro para mí.

$M R$ : ¿Es crucial entonces la primera frase en una narración?

$C P R$ : Por supuesto. Yo soy muy cuidadosa para enganchar con la primera frase. Hay un cuento mío inédito, que es la primera vez que se edita que se llama "Un problema de secreciones”. Título que me parece perfecto para el cuento. Estuve unos diez años para escribir este cuento. ¿Por qué? Bien, no sé si escuché o leí, en algún momento, en esos diez años que alguien había ganado una carrera, una maratón. El hombre se había divorciado, y en el momento de divorciarse estaba muy triste, muy deprimido y lloraba. Lloraba mucho. 
Se había empezado a entrenar en un gimnasio, y lloraba todo el tiempo. Más o menos eso es lo que yo escuché en algún lugar, o leí en algún lugar. Me pareció una idea fenomenal que fuera una mujer. "Esto es lo que yo tengo que escribir”, me dije. Es una mujer a la cual el marido la deja con dos niños y la mujer no sabe qué hacer con su vida, y vive en un barrio por el que sale a llorar todas las mañanas dando vueltas corriendo alrededor de la manzana. ¡Perfecto! Eso era justo lo que quería escribir. Pero yo nunca empiezo a escribir, o tomo apuntes, hasta que no tengo la primera frase. ¿Por qué? Porque sé que fracasará. Esa historia que es preciosa, la voy a arruinar si no engancho con la primera frase. Yo no la pienso, yo no la siento porque sé que no me va a salir ninguna. Sé que esa primera frase va a aparecer en algún momento, y que cuando yo más me olvide del tema, va a aparecer. Va a aparecer en medio de un sueño. Va a aparecer en el metro yo a veces no ando con papeles y apunto en un boleto. Durante tres años ningún sueño me reveló la primera frase, y nada. Pasaron cinco años y yo seguía pensando: ¡Qué macana! este cuento a lo mejor se quedará entre otros que no puedo escribir porque no me viene la primera frase. Porque además, la primera frase te da el ángulo del que narra. ¿Quién va a contar la historia?, por ejemplo. ¿La va a contar ella?. ¿Quién cuenta esta historia? Entonces, una vez, mientras estoy durmiendo me despierto a las tres de la mañana con una pesadilla horrible y escucho la frase: "La mujer pasó corriendo frente a la ventana, y a él le pareció una hora muy temprana para llorar”. Entonces encendí la luz, con bronca porque me había despertado y ahora no iba a poder volver a dormir, agarré lo que tenía, un recorte de diario y apunté la frase con un bolígrafo. La dejé en la mesita otros tres años. Un día que tenía ganas de escribir, la fui a buscar, la saqué y escribí de un tirón el cuento. “Tiré del ovillo”, así lo llamo yo. De esa frase salió todo, porque si tú miras, está el tema central. Es decir, hay una mujer. Pasó corriendo frente a la ventana, y a él, que es el que narra, le pareció una hora demasiado temprana para llorar.

$M R$ : ¿Eso es a lo que tú llamas el "enganche”?

$C P R$ : Seguro. Esta frase seduce a cualquier lector. Le estoy creando una cantidad de enigmas. ¿Qué le pasa a esta mujer que está llorando? ¿Quién es que la mira y que se da cuenta de que es muy temprano para llorar? Así, el cuento salió perfecto.

$M R:$ ¿Puede que ocurra al revés, que tengas la primera frase y no el resto?

$C P R$ : Sí, otras veces tengo la primera frase, me la sé de memoria, y por pereza no tengo ganas de escribir. Yo soy muy perezosa para escribir. Tengo mil ideas por escribir, y están ahí. Yo sé que cuando tenga ganas, teniendo esa frase, saldrá todo el resto. Está resuelto. Otro escritor escribirá de otra manera. Vargas Llosa tiene que hacer un plan estricto. Tiene que saber lo que pasa. Si yo sé lo que pasa, me aburro. Me aburro horriblemente. Por ejemplo, tú verás que ninguna anécdota que cuento la voy a escribir. Aunque sea la mejor anécdota del mundo, porque ya la he resuelto al contarla. Entonces, para mí, no tiene ninguna incógnita. Yo también escribo como si fuera a descifrar una ecuación, un teorema. Ahí está la primera frase, y tiene que ser perfecta. Es decir, el desarrollo tiene que ser el único posible y el más riguroso desde esa primera frase. Entonces, el texto se va creando a sí mismo en ese sentido. Pero claro, recoge todas tus preocupaciones, tus sentimientos. Cuando yo digo que se escribe con el inconsciente, quiero decir que hay un trabajo que no pasa por la consciencia, pero después, claro, hay elementos racionales. Es toda tu vida la que en último término se refleja en un texto.

MR: Cristina, en Norteamérica, más que nada, se ha visto últimamente, una reacción bastante negativa con respecto a la literatura y su función dentro del marco académico. 
CPR: Aquí también.

$M R$ : De acuerdo a eso, ¿̇iensas tú que la literatura como tal está perdiendo su vigencia, y cuál es la función que tú percibes que la literatura debe tener en este nuevo siglo que se aproxima?

$C P R$ : Eso es muy difícil de saber, pero soy consciente de que hay una crisis del concepto tradicional de literatura. A veces pienso que lo que puede pasar es que, digamos, desde mi punto de vista estrictamente narrativo, yo creo que narra mejor el cine y la televisión que la literatura. ¿¿Qué quiere decir que narra mejor? Por ejemplo, para un espectador primitivo. La imagen es una manera de aprehender la realidad más primitiva que el pensamiento, o que el símbolo. Pero, evidentemente, vivimos en una sociedad visual, y por lo tanto, primitiva, como las que tenían que hacer el pictograma. Yo, por ejemplo, creo que la frase: "Una imagen vale más que mil palabras", es un desatino, puesto que si yo en este momento te muestro a ti una foto de una niñita corriendo desnuda y gritando, tú puedes pensar, por ejemplo, que esa niñita está corriendo porque hay un violador detrás que no está fotografiado. Que esa niñita está huyendo de Yugoeslavia. Que esa niñita está huyendo de Brasil, o puede ser la que huyó de Vietnam con el Napal. O sea, que es al revés. La imagen necesita la interpretación. Las imágenes nosotros las decodificamos, y el texto ayuda a decodificar imágenes. La propia cruz, por ejemplo. Si yo dibujo una cruz aquí en este momento, tú puedes pensar: símbolo cristiano, farmacia, signo de más.

$M R$ : No sabe escribir o firmar.

$C P R$ : Exacto. La literatura trabaja con palabras que son conceptos por un lado, y por el otro lado son sonidos. La imagen trabaja solamente con la imagen, pero se apoya muchas veces en el diálogo, porque hay que hacerse entender. Mi sobrino interpretó una escena de amor sin palabras diciendo —_ “Qué pasa con estos dos? ¿Por qué se están peleando?” Por eso creo que narrativamente tiene más impacto la imagen. Los "grandes relatos” se dan por televisión o cine. Ahora bien, ¿hay otra cosa aparte de los grandes relatos? Yo creo que sí. ¿Para qué cuentas algo si no es para enseñar algo? Hay cosas que no se pueden traducir en imágenes. Hay emociones que no encuentran una imagen que las explique. Para mí, la prueba de que algo es literario es que no se puede llevar al cine. Ahora bien, dicho esto, yo creo que queda un campo para la literatura que es justamente ese campo más profundo en el que no se busca tanto entretener con un relato, sino la significación de ese relato. Ese campo que se acerca casi más a la psicología o a la filosofía, que a lo meramente narrativo. Pero incluso en las gestas o en las epopeyas, hay cosas que son pura literatura. Por ejemplo en La Ilíada, cuando la madre de Héctor está asustada porque Héctor se va a enfrentar a Aquiles, y teme que Aquiles lo mate. La madre le ruega que no vaya a pelear y no sabe qué hacer para que Héctor no se enfrente a Aquiles. En lugar de decirle: "hijo mío", le dice: "querido pimpollo a quien parí"; eso es la literatura. O sea, la literatura empieza cuando uno deja de nombrar las cosas de una manera directa. Empieza con el sentido figurado. Por lo tanto yo creo que va a existir. Otra cosa es que se pregunte: ¿cuántos lectores va a tener? Pero creo que esa es una pregunta que no afecta lo literario. ¿Por qué no lo afecta?, por una perversión de la industria actual, tanto en los Estados Unidos como en España. El trabajo del escritor es escribir bien, según la tradición literaria. En respuesta a esa tradición, discutiéndola, subvirtiéndola. La labor del editor es elegir buenos textos, y la del vendedor y del distribuidor, venderlos. No puede ser que a mí me planteen el problema de vender un 
libro mío. Ese no es mi problema, ni el problema del editor. Ahora, si todo está cambiado, si todos los trabajos están pervertidos, y resulta que a mí, cuando escribo un libro me dicen: “Bueno, y yo, ¿cómo voy a vender esto?” ¡No, no, esa pregunta no es para mí!. Yo escribo esto que es lo que creo que tengo que escribir según todo lo que se ha escrito hasta ahora. Entiendo que puede haber otro tipo de escritor, mucho más posmoderno, no interesado en la posteridad, no interesado en trascender lo inmediato. Un escritor que escriba libros para usar y tirar, para leer y tirar. Me imagino que eso implica mediocridad, porque evidentemente, el que no siente que puede apostar por la posteridad, tiene que apostar por el presente.

$M R$ : Y también hay lectores que no están interesados o preparados para establecer ese proceso de inmersión con el texto; los que quieren leer para pasar el tiempo.

$C P R$ : Exactamente. Aparte de eso, estamos viviendo un fin de siglo donde la imagen vale más que lo que se hace. En este momento, lo importante es aparecer en los medios, no ser o hacer. Por ejemplo, a mí hay una cantidad de gente que me reconoce si salgo en televisión. No saben qué hago. Entonces me dicen:- “Ud. apareció en televisión a ver ¿qué era?” Le digo: - “Mire, torera, no soy” (se ríe) Me contestan: — “¡Ah! debe ser escritora”. Pero eso no les conduce a comprar el libro. O sea, que lo importante, es figurar. Esa es una perversión de la publicidad, en la que ahora se gastan millones en un rótulo luminoso, pero no es un dinero destinado a promocionar el producto y a recuperar, por lo tanto, la inversión, sino a aparecer, a significar que uno está presente. Ya no importa lo que tú haces, sino tu imagen, tu rostro. Un rostro que además no dice nada. Un rostro que tiene además connotaciones muy primitivas para el que lo mira. Sólo sabe que es alguien importante porque lo vio en la televisión.

$M R$ : Hugo Verani opina que a raíz del exilio se ha perdido algo de tu "juego hedonista de regodearse con la fastuosidad del lenguaje”. ¿Qué opinas tú de esta percepción sobre tu escritura?

$C P R$ : Yo creo que en cada texto, es lo que tú quieres decir lo que impone el estilo. Yo no elijo el estilo primero, sino que es lo que yo quiero decir quien me impone ese estilo. En algunos casos entonces, sí es correcto que yo juegue, y en otros el jugar me distraería al lector de lo que quiero decir. Pienso que eso está determinado por el tema y por las emociones que quiero causar. Además, a veces, hay juegos que a los lectores se les escapan. En la medida que yo te digo que no hay una sola palabra de un texto mío que yo no pueda justificar como escritora, cuando no juego, yo sé por qué no juego, y cuando juego, sé por qué juego. Lo que sí es verdad, y en esto estoy de acuerdo con Verani, es que quizás con lo que sí he roto completamente, es con jugar por jugar. Podríamos llamarlo el surrealismo. Yo no tolero la arbitrariedad en un texto literario, y en un cuadro tampoco. En la vida no hay nada más significativo que el juego. Además, en la vida cuando tú ves jugar a alguien, tú lo conoces. El juego es totalmente revelador, pero hay que saber mirar a quien juega y saber interpretar.

$M R$ : Siguiendo con el tema del texto, ¿¿en qué se parecen, dirías tú, el acto de creación de un libro, un texto, y el acto amoroso entre dos seres que se entregan sin reparos?

$C P R$ : Un texto, si es importante, es un texto que tiene que intentar llegar a las zonas más profundas, aquéllas que están reprimidas por el Yo. Mi Yo rechaza a los violadores, pero, ¡cómo los entiende mi inconsciente!, hasta qué punto los entiende y cómo me puedo poner. Hay una frase que se le atribuye a Goethe que escribió: "Nada de lo humano me es ajeno”. Goethe, que era muy tramposo y muy culto, le estaba copiando a Terencio. La frase 
es estupenda porque quiere decir que todos nosotros tenemos en nuestra interioridad la posibilidad de sentir todo, y lo haremos según nuestro Yo y los pactos sociales en los que estemos. Yo, como escritora, tengo que tener la capacidad de comprenderlo todo y de ponerme en la piel, incluso de lo que le pueda repugnar a Cristina Peri Rossi. Ahora, después mis elecciones irán por otro lado, pero yo no puedo pretender ser una gran escritora y decir “esto no lo entiendo". Por supuesto que están mis limitaciones. Yo puedo decir: esto lo comprendo, pero sé mis carencias. Por ejemplo, no tengo ninguna facilidad para el realismo. No me interesa. Entonces, nunca voy a ser una escritora realista. Eso, desde cierto punto de vista, puede ser una limitación. Pero yo estoy hablando de otra cosa, estoy hablando de que hay que tratar de ponerse en la piel del otro, y hacer el amor con otro, es ponerse en el lugar del otro. Tienes que ponerte en el lugar del otro para complacerlo sin indicaciones. Es entrar en el inconsciente del otro.

$M R$ : Adelantarse a lo que quiere.

$C P R$ : Sí. Y en último término, gozar con el deseo del otro. Son dos propuestas eróticas en el sentido filosófico de la palabra “erotismo”. El erotismo empieza donde termina el sexo y comienza la imaginación; y no hay escritura que no nazca de la imaginación. Justamente por esto son dos actos muy comprometidos. Uno puede quedar tan extenuado de una pasión amorosa como de escribir. Así quedé yo después de escribir Desastres íntimos (1997). No quería que nadie me hablara de ningún problema psicológico. Aborrecía el psiquismo de cualquiera. Uno para escribir bien tiene que enchastrarse los dedos. La diferencia con un psicoanalista es que el psicoanalista tiene, permanentemente, que contener al Otro, pero estableciendo una distancia. Yo no puedo escribir una novela sobre el juego como La última noche de Dostoievski (1992), sin convertirme durante mucho tiempo en una jugadora, porque si sólo observo, va a ser una escritura fría y muy exterior, y yo tengo que ser mis personajes. Lo que me pasó con Solitario de amor fue muy claro en este sentido. Yo termino Solitario de amor y cada vez que alguien me habla bien de Aída, me pongo a defender al Otro y detesto a Aída. Pero si alguien me habla bien del protagonista, me pongo a defender a Aída. O sea, hay partes mías en ambos. Yo no soy más Aída que el Otro, pero los dos son igualmente míos. Es lo que pasa con los hijos cuando tú no quieres que tu corazón esté dividido. Con la escritura te pasa lo mismo. No quieres que un personaje guste más que otro. Salvo que, deliberadamente, construyas un personaje que tú detestes y vuelques tu odio; entonces lo que tú quieres es que todos lo odien, pero yo nunca he odiado a un personaje.

MR: La palabra y la amada surgen en tus textos como el sustento y la forma de sobrevivencia de la experiencia de vida. ¿Existe una predominancia de una o de otra, o crees tú que se complementan en el proceso creativo para mantener al ser, para enriquecerlo?

$C P R$ : En la medida que el amor es un acto de seducción, hablando a los demás uno seduce. Hablar es entregar cosas.

$M R$ : Pero al hablar uno se expone.

$C P R$ : ¿Es que vale la pena no exponerse? Por ejemplo, yo que no tengo ni un gramo de frivolidad — mi limitación está en que el registro de la frivolidad no existe para mípienso en alguna conversación donde no te expongas; ¿̇me puede seducir tal conversación? Es que yo no tengo ganas de tener esa conversación.

MR: La vulnerabilidad es importante, ¿no crees? 
$C P R$ : Es en el único lugar donde eres tú realmente. Donde eres vulnerable, eres tú misma. Todas las demás son defensas del Yo. Cuando no son mis construcciones defensivas, ¿no? Es ahí donde está el Otro. Por eso es que te puedes llevar sorpresas. Cuando asumes tu fragilidad, estás asumiendo las partes no amuralladas por el Yo. A mí no me interesa tener relaciones donde esa vulnerabilidad no esté expuesta. No me interesa tener relaciones de Yo a Yo; porque son las partes que me parecen más superficiales del ser humano. Me gusta el lugar donde el Otro dice: “Tengo miedo”, o "Me gusta mucho"; y el Otro tiembla, y entonces yo también puedo temblar. Si yo tiemblo, el Otro también va a temblar. Si yo me pertrecho y me fortalezco, el Otro también va a hacer lo mismo. Darle la mano al Otro y decirle: “Tengo miedo”. A mí, a veces me parece que, por ejemplo, quitarse la ropa delante del Otro es uno de los actos más terribles. Estás mostrándote como si perdieras todas las defensas que te ha dado la cultura. Estás ahí, sin la defensa de la ropa, de los tics. Es tremenda la fuerza que tiene que ser la libido para que te animes a desnudarte delante del Otro. El Otro tiene que tener una mirada suficientemente acogedora; te tiene que contener lo suficiente como para que te animes a mostrarte en tu vulnerabilidad frente al Otro.

MR: ¿¿Opinas tú que existe una yuxtaposición entre la literatura y la vida?, y de ser así, ¿en qué consiste?

$C P R$ : Yo tengo un libro inédito de aforismos, de pensamientos y anécdotas de mi vida que empieza con una que dice que en una reunión social en que hay gente conversando, se preguntan si la literatura y la vida son lo mismo, y entonces alguien contesta — yo - : "Si fuera lo mismo, una estaría de más”. No es un espejo la literatura. Justamente, creo que la literatura llena los huecos de la vida. Se alimenta de los fallos de la vida. Por eso leemos, porque comprendemos mejor que en la vida. La vida es más deshilvanada, más dispersa. En toda vida hay momentos de aburrimiento. La intensidad que tiene un texto uno la puede conseguir en la pasión, pero tampoco puede estar todo el día en la pasión porque uno se agota, se cansa. La pasión provoca estrés, la falta de pasión provoca depresión. También hay que preguntarse hasta qué punto uno sabe que corre riesgos en la relación con el Otro. Lo que es si la presencia de alguien te puede hacer sonreír y su ausencia te puede hundir en la miseria, quiere decir que tenemos una relación muy mala con el amor, porque nos tiene que parecer peligrosísimo eso. Uno desearía ser inmune a todo, ¿viste?, y entonces se aburriría increíblemente. Si la vida fuera así siempre, sería terrible. Estamos oscilando entre la necesidad de que alguien nos atraiga y nos conduzca a esos abismos en que asumes tu fragilidad, y también con pánico, estamos huyendo de eso. Y lo hacemos incluso los que hemos reflexionado más sobre estas cosas. Yo, por ejemplo, me fastidio porque cuando me enamoro no me siento inteligente. Como para mí es muy importante ser inteligente Cristina Peri Rossi tiene esa debilidad - cuando estoy enamorada siento que no se me ocurren cosas inteligentes.

$M R$ : Es que el Otro te absorbe.

$C P R$ : Sí, estoy absorbida en la contemplación de los maravillosos gestos de la mujer a la que amo. No se me ocurre ninguna frase inteligente. Entonces, me siento mal porque me digo que esta persona me debe de querer porque yo soy inteligente, $\mathrm{y}$ yo estoy haciendo el papel de una imbécil total. Uno mismo se siente inseguro en el amor. Uno cree que se quiere a sí mismo por ciertas cosas. "Yo me quiero por esto”. Y el Otro, de pronto, te quiere 
por lo que tú te sientes más insegura del mundo, ¿no? El amor te coloca en una situación inestable. Esa es la fuerza de la pasión. En la pasión sentimos que estamos en peligro. “Pasión” viene de “padecer”. La pasión te plantea conflicto entre el Otro y el mundo. Cuando estás apasionada, el estar con esa persona te consume y te apartas solamente para volver a desearla. Esto, a mí misma me plantea un conflicto. El Yo empieza a decir: "Hace tres años que no escribes". "Hace dos años que no vas a una conferencia". Por eso es que yo, en Solitario de amor, lo planteo. Es el Otro o el mundo. Pero eso son las pasiones, que no es lo mismo que el amor. Hay amores sin sexo. El sexo no es determinante del amor. Yo, a las personas que amo, las puedo amar intensamente sin hacer el amor. No pienso en el sexo como puedo pensar en la pasión. En la pasión el sexo me parece muy revelador del Otro. Es en el lugar donde quiero estar. Por eso es que la pasión nos coloca en una situación entre el mundo y el Otro. Aun así, hay pasiones donde uno puede estar apasionado y desdoblarse y observar lo que le está pasando. Éstas son las pasiones más dolorosas porque uno ve que se está hundiendo, y que en último término está tratando de descubrir cosas que quizás sería mejor no descubrir. No porque sean “negativas”, sino porque no hay por qué tener relaciones tan profundas. Quizás las relaciones tan profundas sólo son las relaciones con la madre en el útero, y cualquier otra pasión lo que intenta es recuperar ésa. Yo pienso que sí, que las pasiones en el fondo lo que ponen en juego es esa unidad que hubo con la madre. La fantasía es que ahora la vas a poder controlar. La vas a poder gozar y la vas a poder repetir. Esto es completamente falso porque en la separación hubo una angustia que por suerte no recuerdas. Yo, en un momento, me hice consciente de que el vínculo que intentaba muchas veces reconstruir, era éste. Por otra parte, no se explicaría esta devoción de los hombres y de algunas mujeres por los senos, si no fuera que el seno es el pecho bueno. Es de donde viene la vida, el amor y las cosas reconfortantes y agradables. No tiene nada que ver con que seas hombre o mujer, o lo que sea, uno está buscando esa experiencia que hombres y mujeres compartimos, que fue: “Había un pecho que suministraba”. Era el exterior bueno. Es decir de ahí venía lo bueno. Lo bueno se necesita cuando uno está abocado a un estímulo hostil del cual es difícil recibir cosas buenas. Entonces, uno dice, por lo menos, en la cama, que me den el pecho bueno otra vez, ¿viste? Lo que pasa es que es peligroso porque, claro, si lo intentas recuperar tienes que colocarte en la situación de volver a ser un bebé. Eso es lo que intenté al escribir Solitario de amor. Creo que se ha escrito poco sobre eso. Mientras el falo y el pene están llenos de conotaciones agresivas de "espadas”, “obeliscos”; el pecho es tan importante; por eso es que yo estoy totalmente en contra de la teoría freudiana en cuanto a la mujer. Yo creo que la mujer no está desprovista de pene. El pene son los senos de la mujer. Lo que pasa es que, como los usa fundamentalmente en la maternidad, es el pecho "bueno".

$M R$ : No es un arma.

$C P R$ : No siempre, porque algunas mujeres los usan como armas de agresión. Yo tengo una amiga que camina echada hacia adelante y usa los senos para agredir en muchos casos. A mí me parece fabuloso e incluso le escribí un poema. Ahí me di cuenta de la dimensión fálica que podía tener el seno. Siempre le había visto la dimensión del pecho “bueno”. Esta amiga agrede a hombres y mujeres con sus senos. Ella misma está muy orgullosa de aquello, y trata de que tú lo veas aunque no quieras verlo porque es su arma. Es su arma. 
MR: En tu trabajo aparece constantemente la idea del deseo como fuerza motivadora. ¿Qué opinas tú que mata al deseo? ¿La desilusión, la mezquindad, la traición?, para mencionar algunos hechos.

$C P R$ : Es muy difícil fijar el deseo, porque si viviéramos en un mundo hedonista donde lo más importante fuera el placer, se le podría dedicar muchísimo tiempo. En las vidas que llevamos, en que el Yo tiene tanta importancia, nadie quiere ser famoso porque tiene una buena cama. Es una cosa íntima ¿no?... La gente quiere ser famosa porque gana dinero, porque escribe bien, porque da magníficas clases, porque tiene industria. Digamos, el deseo se convierte en deseos de otras cosas. Se diversifica, entonces ya no es el deseo de esa persona, el deseo erótico por excelencia, sino que se convierte en el "deseo más dinero, más salud, más belleza”. Entonces claro, cuando hablamos de deseo, vamos a ver, ¿de qué estamos hablando?. El deseo erótico es uno de los deseos, pero es un deseo que lo puedes desplazar a otras cosas.

$M R$ : A mí por ejemplo me apasiona enseñar. Pero si un día encuentro que eso se pierde, ¿lo puedo recuperar?

$C P R$ : Yo creo que una vez que deseaste vuelves a desear. Si quieres, si te lo permites. Todo lo que has deseado alguna vez, forma parte de ti. Respondió a alguna pulsión. Por algo lo investiste. Lo cual se contradice con el hecho de que mucha gente dice; incluso tengo un poema que dice: "Líbranos, Señor,/ de encontrarnos,/ años después,/ con nuestros grandes amores”. ${ }^{1}$ ¿Por qué? Porque cuando nos encontramos con el "gran amor" ya lo hemos dejado, nos costó un dolor horrible hacerlo, y hemos colocado la libido en otro lugar. Si tienes una gran lucidez y te permites libertad contigo misma —a mí me pasa, cuando me encuentro con grandes amores — te justificas. Siempre justifico mi deseo. Hay un momento en que sé perfectamente que podría volver a desear a esa persona aunque quizá no me convenga pero es un deseo que yo sigo reconociendo.

$M R$ : Entonces el deseo para ti queda latente.

$C P R$ : Sí, porque yo tengo una concepción totalmente circular del tiempo y creo que nada pasa. Por eso es que a mí los cambios me vuelven loca. A mí un cambio es la cosa que me puede poner peor en el mundo, porque yo creo que todo está, siempre. Si me cambias de ambiente, de ciudad, me vuelvo loca. Hasta que me doy cuenta de que no, sigue estando todo, aunque no lo vea, está. Está todo. Y si no está, igual es porque no se quiere, pero podría estar. Podría estar. La única cosa que se contradice con esto es que somos mortales. Quizás estás de otra manera. Los deseos no son muy fieles. El problema es si quieres cumplirlo, de qué manera lo quieres cumplir, y si el otro responde. Porque quizás el otro puede decir que no, y se acabó. Depende también del grado de neurosis. Los que somos muy neuróticos queremos repetir siempre. El deseo es siempre una pregunta, nunca es una respuesta. ¿Qué deseo cuando deseo? Y vamos dándole distintas respuestas. ¿Quién puede confesarse en serio lo qué desea? Te lo puedes decir en el interior. Quizás los artistas tenemos más osadía porque tenemos menos represiones. La libido es una fuerza. El objeto es hasta cierto punto, irrelevante. Eso lo saben mejor los hombres por su aparato genital. El hombre está acostumbrado a no preguntarse por qué tiene una erección. A las mujeres al no tener algo erecto, el Yo nos dice: “¿y cómo se te ocurre desear esto?” Ya está reprimiendo, ya está

${ }^{1}$ Este poema lleva por título “Oración” y está en el libro Inmovilidad de los barcos (Zarautz: Bassarai, 1997). 
poniendo la censura. Ellos tienen una relación más suelta por su biología. Y me imagino que si las mujeres estamos hechas así, es porque, dado que podemos ser madres, un deseo demasiado libre de las mujeres desestabilizaría la sociedad. La mujer tiene que ser madre.

$M R$ : Goethe dijo que "él fue al bosque sólo para caminar y no con el propósito de encontrarse con un tesoro”, ¿'es esto algo parecido a lo que ocurre con el proceso creativo, tú empiezas y nunca sabes a dónde vas a llegar?

$C P R$ : Yo me dejo llevar. Quiero conocer al mismo tiempo que el lector. Por eso, en La última noche, con referencia al juego, yo había tenido algunos períodos de mi vida donde había jugado en el casino. Para evadirme de ciertas angustias, jugaba. Pero desde que vine a España nunca había jugado a nada, y me empezó la preocupación intelectual. Nunca había entrado a un bingo. Un día entré. Empecé a observar. Yo estaba escribiendo otra novela. La tercera noche, fui, observé, llegué a casa y, como una posesa, escribí a mano las cinco primeras páginas. Abandoné por completo la otra novela. Yo lo que quiero ver es qué pasa, y para eso me tengo que dejar atrapar, para vivirlo yo, y entonces poder jugar con todas las posibilidades. Entonces empecé a tener una relación con el juego totalmente lúdica, erótica. Jugaba y ganaba mucho más de lo que me correspondía. El azar me favorecía porque yo estaba muy libidinal. Cuando tú estás muy libidinal con un tema todo parece desconectado. Empecé a recordar historias de juegos, cosas que me habían pasado antes cuando yo había jugado. Cosas que me habían pasado observando, por ejemplo, algo sin importancia, estaba en un bar con una amiga y habían acabado de instalar una tragaperras. Mientras hablábamos con esta amiga, yo observaba la tragaperras que estaba vacía. En eso entra una pareja, no joven. El tipo mayor, un don Juan con pelo cano que estaba tratando de ligar posiblemente con la viuda, cincuentona, medio morochita, no muy acostumbrada a estar en bares. Entonces él le abre la puerta, la hace pasar, y ella mira la máquina y dice: — “Y esto ¿qué es?” —_Esto es una máquina tragaperras”. Ella contesta: “¡Ah!”. “Y se gana así” pone una moneda y gana premio. ¡Hasta qué punto esta máquina capta la libido!. La mujer queda azorada, y el hombre dice inmediatamente: "Para ti, querida”. "Esta máquina funciona con impulsos eróticos”, le dije a mi amiga. El tipo ligó a la mujer y a la máquina. La máquina captó algo de energía libidinal en los movimientos que el hombre hizo, que le cambió el programa, porque además pasó una cosa insólita, la mujer se quedó con el dinero y el hombre le sugiere que pruebe ella. Ella pone una moneda y sale otra vez el premio. Yo conozco los programas de ordenador y eso no es posible. Se necesitan cincuenta mil jugadas para que se repita el premio. O sea, desestabilizaron el programa. Fue una instancia erótica. Al decidir escribir una novela te empiezan a fluir ideas por todos lados, y empiezan a pasar "aparentes" casualidades que tienen que ver con el hecho de que tú estás captando todo lo que tiene que ver con ese tema. Estás ampliando enormemente tu experiencia, pero tú la estás conociendo. Por ejemplo, yo creía que el juego de cartones y números era uno de los que yo aborrecía, que la lotería de cartones era la cosa más aburrida porque en mi casa se jugaba cuando yo era chica y yo me aburría. Y de pronto me encuentro enrollada. ¿Por qué?, porque quiero estar enrollada. Empiezo a escribir la novela y al hacerlo, gano de una manera no normal. Mientras escribo, gano una cantidad de veces desproporcionada. Ahí, el objetivo del juego era escribir la novela, investigar, por lo tanto yo hacía horarios completos en el bingo. Entraba a las ocho y salía a las cuatro de la mañana. Entraba a las cinco y cambiaba de lugar 
para observar a la gente. Empiezo a conocer a las vendedoras de cartones. Al mismo tiempo voy escribiendo la novela. En un momento me doy cuenta de que no sólo estoy enganchada con la novela. Lo que me va a pasar es que va a coincidir el final de la novela con el final de la adicción. Es que tengo que cortarla, y voy a sentir el mono de la ausencia de la novela y el mono del juego a la misma vez. Cuando termino la novela, la publico y ya no tengo motivos por los cuales ir al bingo. Pero además, después de terminar la novela yo no tengo ganas de volver a escribir. Hay un tiempo en el que no escribes. Y yo, ¿qué hago con mi vida? Se me acabó lo que investigar. Me encuentro vacía, con una depresión horrorosa y regreso al bingo, pero ya no es lo mismo. Ya no hay motivo.

MR: Generalmente, ¿cuál es tu mayor fuente de inspiración?

$C P R$ : Normalmente yo escucho mucho. A veces escucho el fragmento de una historia, o tiene que ver también con preocupaciones existenciales. De manera que en cada etapa de la vida tiene que ver con todo lo que he vivido hasta ese momento, lo que está en primer plano o en segundo plano. A veces son cosas que vienen del exterior, cosas que he leído en el diario. Con esto, Cortázar estaba de acuerdo, y es que inspiran mucho los escritores que escriben mal. A veces, en un libro malo hay una idea estupenda que quedó desperdiciada horrorosamente, o un detalle. En ese sentido un escritor bueno es castrador. No puede inspirar a nadie. Te inspira alguien que, como no consiguió llevar la idea hasta el final ni desarrollarla, te deja espacio para tu propia elaboración.

MR: En cuanto a los artículos publicados aquí, en España, especialmente, ¿cómo seleccionas tú los temas para los mismos?

$C P R$ : Un poco en la tradición de lo que se hacía en la época de la ilustración, que son apuntes sobre lo cotidiano. La historia, en definitiva, es la sucesión de lo cotidiano. Entonces, creo que cualquier reflexión cabe en un artículo sobre cualquier tema dado que eso es lo que somos cada uno de nosotros en una circunstancia. Entonces, la clasificación no tiene tanto que ver con los temas sino con el hecho de la realidad, de lo que la realidad pone en primer lugar según la circunstancia.

$M R$ : El humor es mucho más agudo, más visible en los artículos que en la novela, por ejemplo, ¿̇no crees? Yo encuentro que en los artículos, el humor surge en una forma más fina.

CPR: Sí, porque es una posición más crítica. Yo creo que mis artículos forman parte del trabajo puramente intelectual. Para mí, el trabajo intelectual es la búsqueda del conocimiento y la crítica al presente. Yo tengo un gran respeto por los escritores que se animaron a enjuiciar al mundo en que les tocó vivir. Para mí una de las obras paradigmáticas de la literatura es Los viajes de Gulliver. Yo creo que desde el espíritu de la ilustración y de la racionalidad, es a la vez la que fue más implacable con lo que era el ser humano y Europa. Entonces, para mí, eso es lo que hace la diferencia entre un artista y un intelectual. El artista trabaja más con la sensibilidad, con la imaginación. El intelectual trabaja con la razón. Yo creo que tengo los dos aspectos. A veces trabajo más con la razón, con la ironía y con el humor un poco sarcástico. Me parece además que la sociedad necesita ser criticada de esa manera.

MR: Claro, además los lectores de esos artículos son distintos generalmente. Son lectores que leen en diversos lugares, por distintos motivos.

$C P R$ : Ahí está, y que muchas veces no son lectores de libros. 
MR: Seguro. Pero, ¿no piensas tú que ésta puede ser una excelente forma de conquistarlos? ¿De seducirlos en cierta manera?

$C P R$ : Ah, sí, sí. Estoy segura de que si yo tengo muchos lectores en España fue porque al poco de llegar empecé a colaborar-y era la única extranjera que lo hacía—en la revista Triunfo, que era la revista emblemática de la izquierda antifranquista de la cual salieron muchos escritores famosos. Yo era la benjamina, la más joven y la única extranjera como te lo mencioné. Un poco, para mí sustituyó a Marcha. Fue la manera de compensar la pérdida de mi participación en Marcha. Triunfo también era un semanario. Es muy difícil de decir desde el punto de vista del periodismo, pero creo que fui una de las primeras que usó el humor del tipo del absurdo que después fue muy rápidamente imitado y con mucho éxito.

MR: ¿A través de los artículos?

CPR: Claro, a través de los artículos de Triunfo. Aquí no se conocía lo que en Estados Unidos se conoce como periodismo de ficción. Por ejemplo yo, en Uruguay, era muy lectora de las columnas de uno de los periodistas más importantes que hubo en los Estados Unidos, que ya debe de ser muy mayor y que hacía un tipo de columna muy satírica. Se traducía y a veces se reproducía en Marcha. Aquí no, en el mundo hispánico eso se había acabado con Larra. Larra había hecho artículos más largos. Ya eran literatura. Aquí no había tradición de eso. Yo sentí que era un terreno en el que yo podía trabajar muy a gusto. La verdad es que cuando escribí para El País, yo creo que gané muchísimos lectores. Parte de los lectores que tengo en el presente son lectores ganados a través de la prensa. Algunos de los artículos de El País fueron incluso dados en los cursos de los institutos. Ahora ya hay mucho más de ese material porque evidentemente, ésta es una sociedad con mucha gente, con mucho movimiento, y claro, ahora yo hago cada vez menos periodismo, pero hace diez o quince años se usaban mis artículos, por ejemplo en la Universidad de Periodismo.

$M R$ : ¿Es pesadumbroso el tener que producir algo en forma regular?

$C P R$ : No, a mí me gustaba y me gusta mucho. A lo que no estaba dispuesta era a escribir algo que no pudiera entrar en mis obras completas, para decirlo de alguna manera. No escribía sólo para ganar dinero, que además lo necesitaba, evidentemente. Pero no hubiera escrito nada de lo que me hubiera tenido que arrepentir. Entonces habrá unos mejores que otros, pero no acepté escribir un artículo con un tema para ganar más lectores. Los temas los elijo yo, desde el punto de vista de la ética profesional, que me parece muy importante para un escritor. Yo me he divertido muchas veces escribiéndolos. Lamento no hacerlo más ahora. No lo he hecho en estos años por otras razones, y esto exige una continuidad. Los tienes que escribir en el momento en que se te ocurren. En una época en Diario16 durante un mes tuve una columna diaria muy breve.

$M R$ : Pero además, debido a la brevedad, ¿no se convierte ésta en un obstáculo para la escritura?

$C P R$ : Si es un margen muy pequeño, sí. La brevedad te condiciona mucho el estilo. Pero digamos, como yo no soy una escritora de un solo estilo. Yo puedo escribir una novela completamente lírica como Solitario de amor, y después otra irónica como La nave de los locos (1984). Esto también a mí me crea esa diversidad que necesito, porque si no, cuando escribes te terminas convirtiendo en la caricatura de ti mismo. Para mí, muchas veces es muy satisfactorio escribir un artículo. Después también, hay muchos artículos que entran dentro 
de lo puramente literario. Digamos, yo he escrito mucho sobre ciertos escritores poco conocidos en los medios españoles pero que a mí me gustan. De la misma manera que he traducido escritores que no se conocían aquí, o he hecho antologías de escritores que me parecían importantes. El agujero que a mí me quedó es el Eros pedagógico. Yo creo parte de mi libido era el Eros pedagógico. Fue una de las cosas que más he lamentado perder. Una de las cosas que realmente he extrañado y que me ha dejado muy frustrada. Yo no creo que el escritor tenga que escribir ni todos los días, ni continuamente. Lo otro, lo pedagógico, te comunica con los demás, te mantiene joven, y por otra parte, desarrolla la interrelación personal que es tan importante. 